\section{DUCTILITY OF REINFORCED CONCRETE SUB FRAME FOR INDUSTRIALIZED BUILDING SYSTEM}

\author{
Ahmed Sabah Aljawadi, Abdul Kadir Marsono*, Che Ros Ismail \\ Department of Structure and Materials, Faculty of Civil Engineering, \\ Universiti Teknologi Malaysia, 81310 UTM Johor Bahru, Johor, \\ Malaysia
}

\author{
Article history \\ Received \\ 9 August 2017 \\ Received in revised form \\ 10 October 2018 \\ Accepted \\ 1 November 2018 \\ Published online \\ 18 February 2019 \\ *Corresponding author
akadir@utm.my
}

\begin{abstract}
An accurate determination of industrialized building system (IBS) frames ductility under alternating lateral loads is the key issue of this study. The performance features of IBS H frame assembly subjected to cyclic lateral pushover test with six attached IBS components are reported. A test scheme of nonlinear elastic sub-frame system is proposed to build an IBS structural building system. This system complies with the requirements of strength and ductility governed by European Codes 2 and 8 . The three models are a conventional reinforced concrete $\mathrm{H}$ frame system $\mathrm{CRCH}$ (Model 1), IBS with steel conventional links as reinforcements IBSHN (Model 2), and special spiral links concrete IBSHS (Model 3). Each model is scaled to 1:5. All models are laboratory examined under cyclic lateral pushover test to failure, where the IBS connections are considered as hybrid partial rigid linking beams to columns. The beam ends are connected to column boxes via a $U$ shaped steel plate. The experimental results of the IBS specimens are compared with the conventional reinforced concrete connection of similar shapes and size in the form of $\mathrm{H}$ sub-frame mechanism tested under the same condition. The models are subjected to cyclic lateral load controlled applied at the beam-column connection. The performance evaluation of IBS connections is made via load displacement hysteresis, ultimate and collapse parameter, ductility index, and surface cracks appearances. The conventional concrete specimen is obviously found to display better strength compared to IBS. Conversely, the ductility of IBS H frame specimen with spiral shear links and conventional closed loop links exhibits superior features compared to the conventional concrete specimen which is beneficial to earthquake engineering. It is demonstrated that the performance of the precast concrete structure is highly dependent on the ductile capacity of connectors to each of the IBS component. This is significant especially at the joints such as the beam-tocolumn connections. Our systematic methods on ductility characterizations of reinforced concrete beams may contribute toward the development of IBS in resisting earthquakes.
\end{abstract}

Keywords: Industrialized building system, H frames, beam-column connection, cyclic lateral push over test, hybrid connection, ductility

\begin{abstract}
Abstrak
Kajian in bertujuan untuk menentukan nilai kemuluran dengan kaedah yang tepat untuk sistem bangunan berindustri (IBS) di kenakan beban datar selang seli. Ciri-ciri prestasi bingkai H IBS terpasang dengan enam komponen IBS dilaporkan melalui skema ujian tak lelurus sistem untuk kegunaan bianan struktur bangunan IBS. Reka bentuk struktur ini mematuhi piawaian Eurocode 2 and 8. Tiga model termasuk set konkrit bertetulang konvensioanl bentuk H, CRCH (Model 1), set IBS dengan keluli ricih konvensional sebagai IBSHN (Model 2) dan keluli ricih bentuk gelung IBSHS Model 3) diuji di makmal. Setiap set di reka pada skala 1:5 dan dikenakan beban sisi meningkat dan berulang sehingga menemui kegagalan. Sambungan pada sistem IBS dianggap jenis separa hibrid bertindak tegar menghubung antara rasuk dan tiang. Elemen keluli bentuk $U$ di hujung rasuk-rasuk disambung kepada kekotak keluli hujung tiang. Keputusan ujian makmal set konvensional dibanding langsung ke set 2 dan 3 model IBS. Beban sisi yang menghasilkan sesaran dikawal sepanjang ujian untuk menilai prestasi sambungan IBS. Prestasi disemak melalui geraf anjakan histeris, jenis keruntuhan, indek kemuluran dan retak yang terhasil. Set konvensional didapati berkekuatan lebih tinggi dari set IBS, tetapi mempunyai kemuluran lebih baik pada set IBS ricih gelung dan diikuti oleh set ricih gelung yang bermanfaat untuk kejuruteraan gampa bumi. la menunjukkan bahawa prestasi struktur konkrit pratuang adalah sangat bergantung kepada kapasiti kemuluran penyambung pada setiap hujung komponen IBS. Kaedah sistematik ini juga memaparkan data pencirian kemuluran rasuk konkrit bertetulang IBS yang boleh menyumbang ke arah pembangunan sistem pasang siap untuk merintang gampa bumi.
\end{abstract}

Kata kunci: Sistem bangunan berindustri, bingkai H, sambungan rasuk-tiang, ujian sisi berulang, sambungan hybrid, kemuluran

(C) 2019 Penerbit UTM Press. All rights reserved 


\subsection{INTRODUCTION}

The enhanced construction features of the Industralized building system (IBS) is becoming more attractive in developing countries compared to the conventional ones IBS represents the concept of prefabrication and industrialization of construction [13]. It is a construction process that utilizes techniques, products, components, or building systems which involve prefabricated components and on-site installation. IBS is able to reduce cost, improve quality, and create complex products with premium finishing for large scale constructions [4, 5]. Automation is introduced into the building realization process to reduce human involvement, improve variation in design, increase production, and minimize assembly. Design, production, and onsite erection are strongly interrelated. Therefore, it is viewed as part of an integrated process that requires planning and coordination. The significant benefits of IBS are reduction in skilled labour onsite, faster construction process, and superior product quality. These advantages of IBS can be realized by educating architects and engineers in a systematic way to integrate design, technology, management, economics, and marketing $[6,7]$. However, successful implementation of IBS for seismic use is critically determinded by their ductile properties. Ductility is the ability of the structures, elements and constituent material properties to deform beyond the elastic limit without any loss of strength and energy accumulation during the loading cycles. It estimates the capacity of the materials system and their components to deform prior to collapse by dissipating a significant amount of energy [8]. The characteristic stress-strain curve is used to express ductility. For the structural element, the momentcurvature, and for the structural assembly forcedisplacement relations are used.

Understanding the structural behaviours of the IBS system and evaluating their performances remain challenging [9]. Generally, a building system is a set of correlated elements that are executed together to enable the designated performance of a building. This includes various technological and managerial procedures for the creation and assembly of these elements. An IBS has several salient features. The main attribute of IBS is the usage of minimum erection, jointing and finishing work onsite for large prefabricated assemblies. Furthermore, most of the building elements are prefabricated offsite at a central facility, where specialized types of equipment and infrastructures are housed. The materials and onsite component handling are extensively mechanized for concrete work. Generally, large standard steel forms, ready-mixed concrete and concrete pumps are used. The structural connectivity in a complete building forms an essential part of the system. Consequently, the structural response depends on the behaviour and the characteristics of the connections. The structural layout, the arrangement of stabilizing units, the design of the structural system (sub-systems), and connections detail must be consistent with the intended structural performance. A satisfactory design is achieved by understanding the connections influences on the flow of forces through a structure under vertical and lor horizontal loads. Thus, the main purpose of the structural connections is to transfer forces between the precast elements in enabling the intended structural interaction when loaded [10].

Several studies have been conducted to evaluate the performance of precast beam-column moment resisting frames under cyclic loading. Castro [11] performed a test on nine two-thirds scale beamcolumn joints including a monolithic specimen and concluded that precast concrete specimens could sustain inelastic deformations, and remained ductile as cast-in-situ specimens. Li et al. [12] studied hybridsteel concrete connections under cyclic load reversals. The precast specimen exhibited adequate ductile behaviour under seismic loading and were consistent with the cast-in-place specimen. Embedment of the steel sections in the joint greatly enhanced the strength (ductility factor by as much as 3.5) of the joint core with the specimens carrying storey shears. Xue and Yang [13] examined the performance of precast concrete connections in a moment resisting frame under cyclic loading. The connections were interior, exterior, $T$, and knee types. Knee connections were observed to be less effective compared to the other variants. All the connections manifested strong column-weak beam failure mechanism. Moreover, these connections performed satisfactorily in seismic conditions with superior strength, ductility, and energy dissipation capacity. Vidjeapriya et al. [14] carried out tests on one-third scale models of two types of precast, and a monolithic beam-column connection under reversed cyclic loading. The precast connections were beamcolumn types with corbel using (i) dowel bar and (ii) dowel bar with cleat angle. The monolithic specimen outperformed the precast specimens in terms of strength and energy dissipation. The ductility of the precast specimen using dowel bar and cleat angle revealed superior behaviour than the referred monolithic specimen. Ghayeb et al. [15] studied the ductility of exterior beam-to-column connection which used monolithic connections and hybrid connections for two reinforced concrete models and two precast concrete models, respectively. The specimens were tested until failure by applying hysteretic reverse cyclic loading. The results exhibited that the hybrid precast concrete specimens showed low and moderate ductile connection which were considered to have agreeable ductility and satisfied the requirements of standard building codes. Furthermore, the monolithic reinforced concrete specimens presented moderate ductile connection.

A test scheme with elastic sub-frame system to construct IBS that fulfils the requirements of strength and ductility governed by EC2 and EC8 [16, 17] was proposed. The failure mechanism, strength, capacity, 
and ductility of two IBS $\mathrm{H}$ sub-frames system and one conventional reinforced concrete $H$ frame in 1:5 scale were inspected. The means of failure of IBS $\mathrm{H}$ frame system to lateral pushover cyclic loading test was identified, and the ductility of reinforced concrete useful for IBS was determined. A new IBS concrete frame with an assembly of beams of 120 $\mathrm{mm}$ height, $60 \mathrm{~mm}$ wide, $1360 \mathrm{~mm}$ length forming a frame of 1:5 scales were utilized. The behaviour of the IBS beam was examined via the pushover test. Properties such as load displacement hysteresis, ultimate and collapse, ductility index and surface cracks appearance were measured to evaluate the performance of IBS connections. Experimental results were analyzed and compared.

\subsection{METHODOLOGY}

Two 1:5 scaled IBS $\mathrm{H}$ frame and conventional reinforced concrete (RC) $\mathrm{H}$ frame were constructed and tested in the structural laboratory. The IBS $\mathrm{H}$ frames consisted of four half columns and full span beam assembled by $U$ shape plates at both ends of the beam, and box plates at one end of each half column. Conventional $\mathrm{H}$ frame $\mathrm{RC}$ was cast as a monolithic system. Effects of shear links of IBS beams and conventional RC on the ductility were inspected. Behaviours of IBS beam and its connection under lateral pushover test were determined. Two concrete cylinders each of $100 \mathrm{~mm}$ diameter and $200 \mathrm{~mm}$ length were submerged in curing water tank to monitor the development of their strength. Load at a constant rate of $3 \mathrm{kN} / \mathrm{sec}$ was applied using compression test machine until the cylinders failed due to crushing. The loading rate was equivalent to $0.38 \mathrm{MPa} / \mathrm{s}$. These cylinders were tested after 28 days of casting, throughout the $\mathrm{H}$ frames verification and conventional RC $\mathrm{H}$ period. Frames specimen testing was started at 46 days after casting and completed at 59 days. During this period the compressive strength of concrete fck was measured to be in the range of 27.174 to $28.049 \mathrm{MPa}$ without any notable change.

Experiments were carried out using the new format of IBS concrete frame system. This is capable of erecting a system of real scale beams of $600 \mathrm{~mm}$ high, $300 \mathrm{~mm}$ wide, and $7000 \mathrm{~mm}$ in length to form a frame of 1:5 scaling. The conventional RC $\mathrm{H}$ frame test specimen ( $\mathrm{CRCH}$ ) was designed following EC2 specifications. The beam of $\mathrm{CRCH}$ as shown in Figure 1 contains typical close loop shear links of $1.5 \mathrm{~mm}$ diameter and four main bars each of $6 \mathrm{~mm}$ diameter as the main flexural reinforcement, and the cover of rebar of $17 \mathrm{~mm}$ thick. The $\mathrm{CRCH}$ frame consists of two half columns with a height of $760 \mathrm{~mm}$ and crosssection $60 \mathrm{~mm} \times 60 \mathrm{~mm}$ with four main bars of $6 \mathrm{~mm}$ diameter each. The casting of concrete of $\mathrm{CRCH}$ was done by pouring concrete into the wood mould.

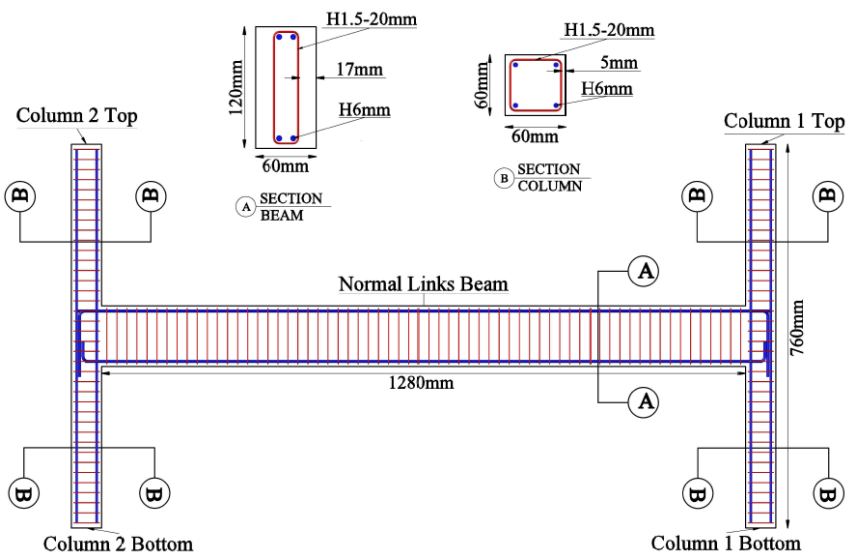

Figure 1 Dimensions and reinforcement details of $\mathrm{CRC} \mathrm{H}$ frame

Figure 2 illustrates a scaled IBS H frame containing close loop shear links of $1.5 \mathrm{~mm}$ diameter with four main longitudinal bars of $6 \mathrm{~mm}$ diameter each. They provide main flexural reinforcement with $17 \mathrm{~mm}$ cover of rebar. IBS columns were cast in a scale of 1:5. Each side of the frame has two half columns consisting of two parts (top half and bottom half) of $330 \mathrm{~mm}$ high and $60 \mathrm{~mm} \times 60 \mathrm{~mm}$ cross-section. This consists of four main bars with a diameter of $6 \mathrm{~mm}$ enclosing spiral shear links of $1.5 \mathrm{~mm}$.

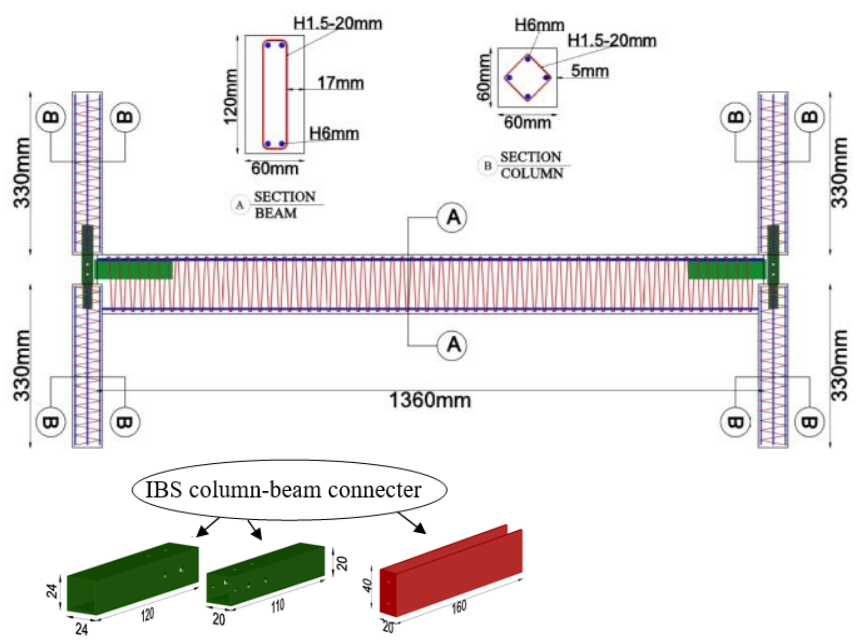

Figure 2 Dimensions and reinforcement details of IBS $\mathrm{H}$ frame with normal links for beam

Figure 3 shows the IBS $\mathrm{H}$ frame holding continuous spiral links of $1.5 \mathrm{~mm}$ diameter. Four main bars each of $6 \mathrm{~mm}$ diameter were provided as main flexural reinforcement with $17 \mathrm{~mm}$ as the cover of rebar. Again, the IBS columns were cast on a scale of 1:5. Each side of the frame had two half columns, and each side consists of two parts (top half and bottom half each $330 \mathrm{~mm}$ high and $60 \mathrm{~mm} \times 60 \mathrm{~mm}$ crosssection enclosing four main bars of $6 \mathrm{~mm}$ diameter. 


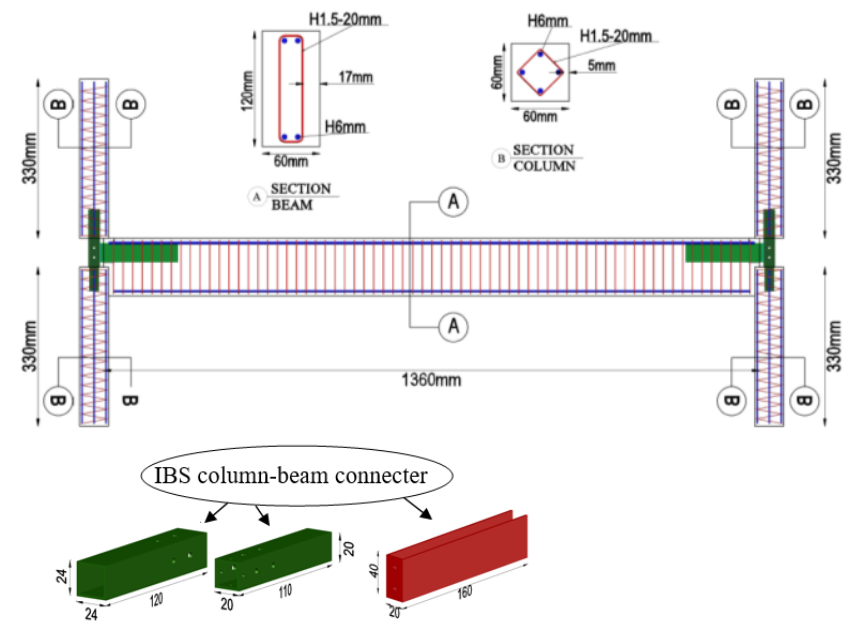

Figure 3 Dimensions and reinforcement details of IBS $\mathrm{H}$ frame with spiral links for beam

Casting of the concrete component of IBS was done by pouring concrete into the wood mould. Each IBS $\mathrm{H}$ model consists of one full span beam, two bottom, and two top columns. IBS $\mathrm{H}$ and $\mathrm{CRC} H$ models were placed in a steel frame for testing. Two steel boxes each of cross-section $60 \mathrm{~mm} \times 60 \mathrm{~mm}$ and height $60 \mathrm{~mm}$ were locked by a long bolt with a strong and heavy steel base to hold the column firmly in place. Load was applied by a hydraulic jack. Two steel channels were used for application of load at two beam-column connections. One load cell was applied to the load jack to measure the load applied to the connections. In addition, a steel plate was inserted between the hydraulic jack and the load cell. The load cell was then connected to a data logger. Two digital inclinometers were attached to the top columns to measure rotation of the column at the beam-to-column connection. Figure 4(a) shows the locations of six LVDTs and their connection to the data logger used to measure important points of displacement, and deflection of IBS $\mathrm{H}$ model. The maximum allowed instrument displacement of four LVDTs is $100 \mathrm{~mm}$. The specimen was placed in the steel fixed rig without allowing any deflection, movement, or rotation before testing. The steel cubes simulating gravity imposed floor load were then put into place. The entire test apparatus was installed and connected to the data acquisition system. An initial reading of all data was taken at this point, and the specimen was then confirmed to be ready for testing. The sub-assemblages were tested within a loading frame as shown schematically in Figure 4 (b).

The purpose of the test was to subject the specimen to repeated cycles of increasing lateral load. Using a manual hydraulic pump, an active horizontal jack pushed the column in one direction until the desired level of load was achieved. The hydraulic pressure was then released in steps until the specimen returned to its neutral point. Finally, the jack was moved to the opposite side of the rig to push the column in the other direction maintaining the same push overload. The horizontal load was recorded against the displacement at the middle of each column at two different points in the beam for each cycle. Sufficient intermediate readings were obtained to outline a hysteretic loop for at least three cycles within each load increment. The endpoints of each loop were monitored for loss of stiffness. If there was no significant loss of stiffness, the load was then increased to the next value. Otherwise, the specimen was subjected to more cycles until the stability limit was reached. The failure load scheduled for IBS H models underwent lateral increments of 1, 1.5, 4 and $6 \mathrm{kN}$. Similarly, the failure load scheduled for $\mathrm{CRC} \mathrm{H}$ model were in steps of $1,1.5,4,6$ and $9 \mathrm{kN}$ according to load protocol of FEMA273/356 [18, 19].

A marker pen was used to spot crack patterns. Relevant data at progressing load paths and zero loads for each cycle were recorded using lasers, inclinometers, and demec points. Tests were continued until signs of specimen failure and collapse appeared. For each tested specimen, the images of crack patterns were taken for reference.

\subsection{RESULTS AND DISCUSSION}

\subsection{Load-Displacement and Crack Patterns}

The load-displacement of IBSHN Column 2 Top (LVDT1), Column 2 Bottom (LVDT2), IBSHN Column 1 Bottom (LVDT5), and Column 1 Top (LVDT6) are shown in Figures 5(a), (b), (c) and (d), respectively. The maximum horizontal displacement at the fourth cyclic loading for LVDTI was found to be $14.66 \mathrm{~mm}$ at $5.9 \mathrm{kN}$. The horizontal displacement at failure point was $23.06 \mathrm{~mm}$ for $6.2 \mathrm{kN}$ load.

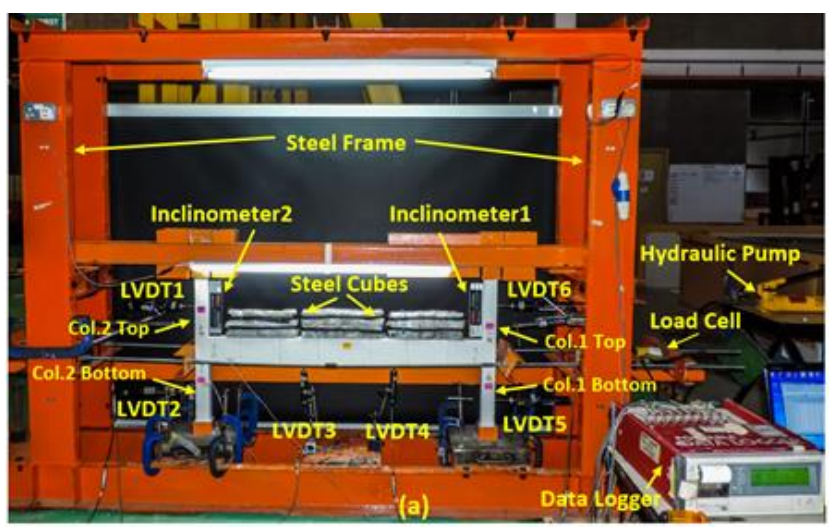




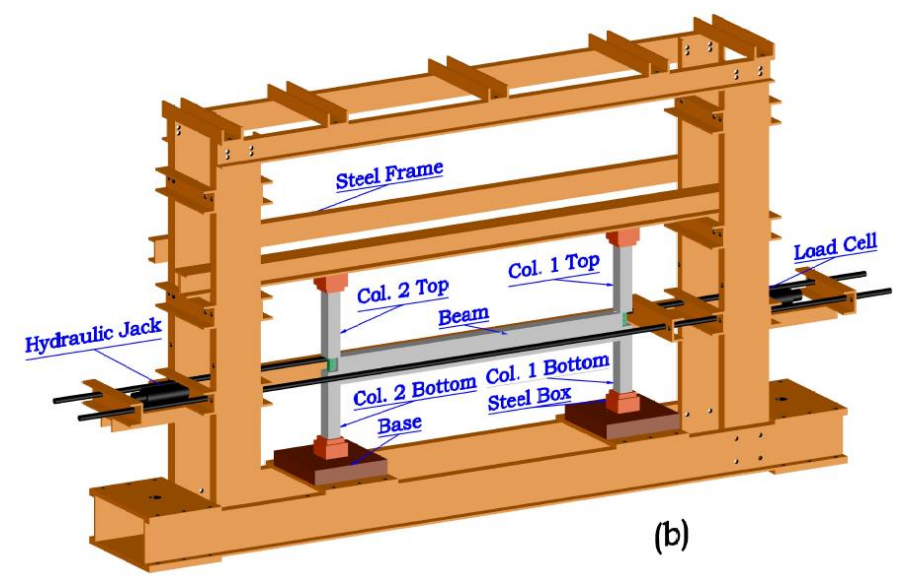

Figure 4 Test setup and instrumentations (a) locations of six LVDTs and (b) sub assemblages testing using loading frame

The maximum horizontal displacement of the fourth cyclic loading for LVDT2 was $14.2 \mathrm{~mm}$ at 5.4 $\mathrm{kN}$. The horizontal displacement and load at failure point were $25.83 \mathrm{~mm}$ and $6.2 \mathrm{kN}$, respectively. Results for LVDT5 (movement of the bottom of the $\mathrm{H}$ frame column) showed the maximum horizontal displacement of $15.5 \mathrm{~mm}$ in the fourth cyclic loading at $5.3 \mathrm{kN}$. The horizontal displacement and load at failure point were observed to be $25.13 \mathrm{~mm}$ and 6.2 $\mathrm{kN}$, respectively. As shown in Figure 5, the maximum horizontal displacement of the fourth cyclic loading for LVDT6 was $0.17 \mathrm{~mm}$ at $5.9 \mathrm{kN}$. Moreover, the horizontal displacement and load at failure point were discerned to be $0.25 \mathrm{~mm}$ and $6.2 \mathrm{kN}$, respectively.

Figure 6 shows a schematic illustration of the crack patterns of the specimen at the end of the third, fourth cycle, and at failure of IBSHN. The IBSHN model does not display noticeable cracks after being subjected tol $\mathrm{kN}$ and $1.5 \mathrm{kN}$ lateral load of cyclic loading. However, the specimen exhibited considerable cracks formed at the edge of the bottom columns and Column 1Top during the $4 \mathrm{kN}$ lateral load cycle. At $6 \mathrm{kN}$ lateral load cycle, the same radial crack lines extended towards the centre of the bottom columns where more cracks were formed. The specimen showed significant crack occurrence at the base of the columns. The $6.2 \mathrm{kN}$ lateral load failure cycle resulted in a few additional cracks with a notable increase in crack widths. Besides, the IBS beam does not display any prominent radial cracks until the end of the test.

With reference to the results of the IBS $\mathrm{H}$ Model test for a beam with spiral links, Figures 7(a), (b), (c), and (d) show the load-displacement curves of IBSHS Column 2 Top (for LVDT1), IBSHS Column 2 Bottom (for LVDT2), IBSHS Column 1 Bottom (for LVDT5) and IBSHS Column 1 Top (for LVDT6), respectively. The maximum horizontal displacement of the fourth cyclic loading for LVDTI was found to be $12.47 \mathrm{~mm}$ at $5 \mathrm{kN}$. The horizontal displacement and load at failure point were $15.56 \mathrm{~mm}$ and $6.2 \mathrm{kN}$, respectively. Results for
LVDT2 (movement at the bottom of the $\mathrm{H}$ frame column) exhibited the maximum horizontal displacement of $-9.77 \mathrm{~mm}$ in the fourth cyclic loading at $-5.7 \mathrm{kN}$. The horizontal displacement and load at failure point were observed to be $8.97 \mathrm{~mm}$ and 6.2 $\mathrm{kN}$, respectively. In addition, the maximum horizontal displacement of the fourth cyclic loading for LVDT5 was $11.85 \mathrm{~mm}$ at $5.4 \mathrm{kN}$.
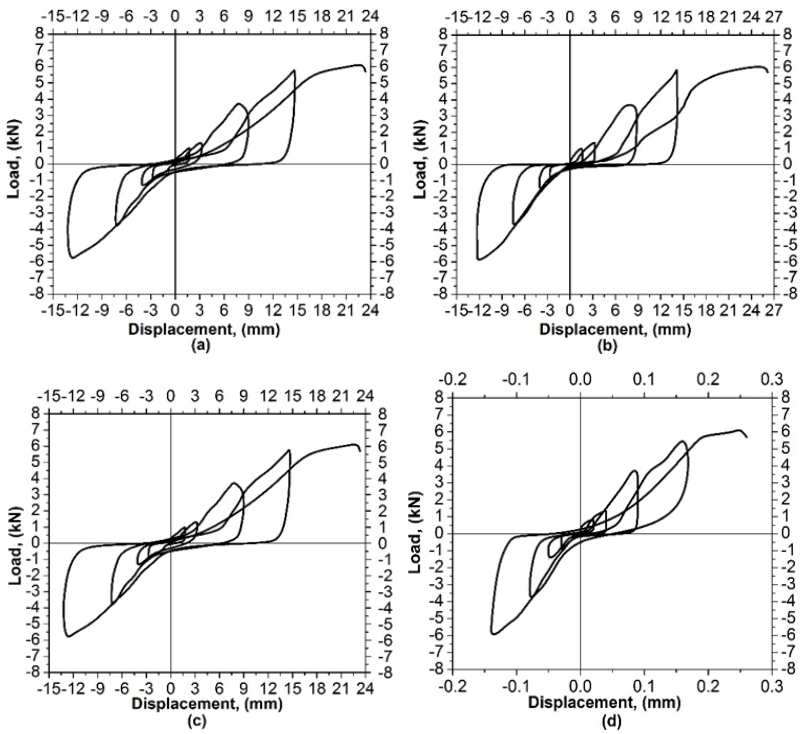

Figure 5 Load-displacement curves of IBSHN (a) Column 2 Top (LVDT1), (b) Column 2 Bottom (LVDT2), (c) Column 1 Bottom (LVDT5) and (d) Column 1 Top (LVDT6)

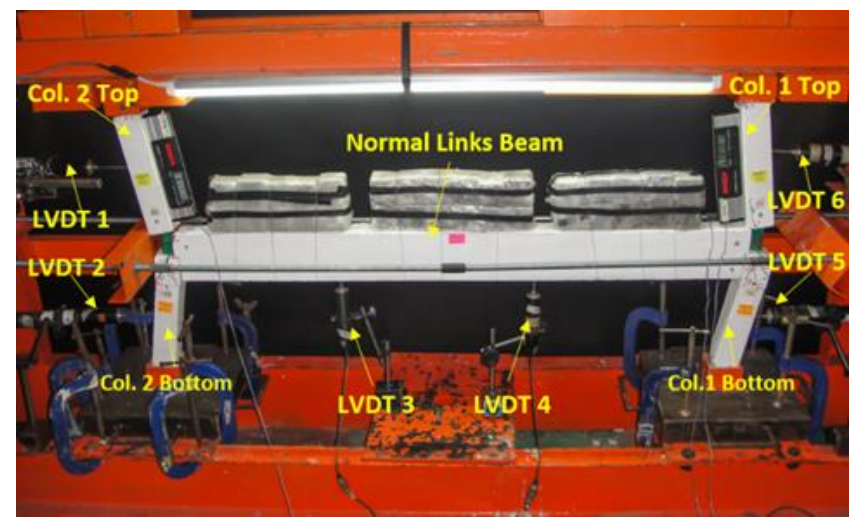

Figure 6 IBSHN model at the end of cyclic loading test (collapse)

The horizontal displacement and load at failure point were determined to be15.52 $\mathrm{mm}$ and $6.2 \mathrm{kN}$, respectively. The maximum horizontal displacement of the fourth cyclic loading for LVDT6 was determined to be $0.12 \mathrm{~mm}$ at $5.8 \mathrm{kN}$. The horizontal displacement and load at failure point were found to be $0.15 \mathrm{~mm}$ and $6.2 \mathrm{kN}$, respectively. 

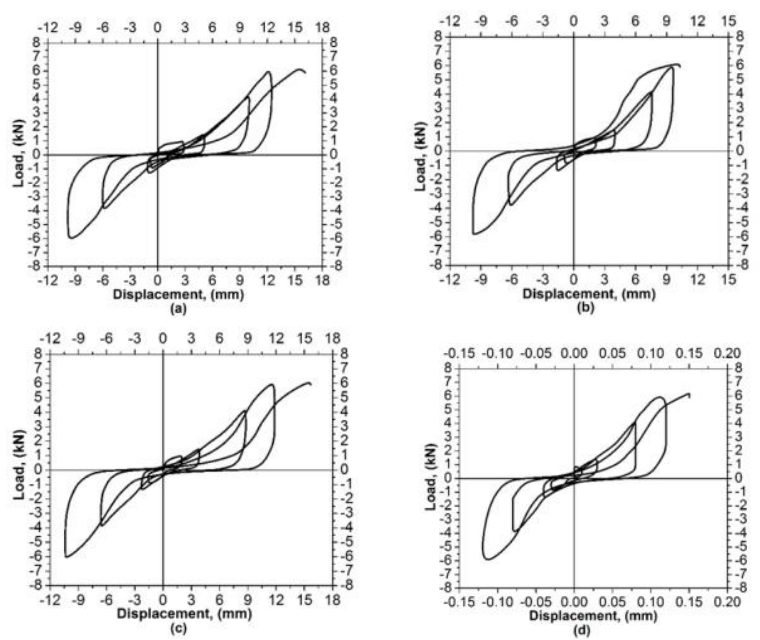

Figure 7 Load-displacement curves of IBSHS (a) Column 2 Top (LVDT1), (b) Column 2 Bottom (LVDT2), c) Column 1 Bottom (LVDT5) and (d) Column 1 Top (LVDT6)

Figure 8 shows the observed surface crack of IBSHS. The crack patterns of the specimen appearing at the end of the third, fourth cycle and at failure can be are clearly evidenced. During the experiment, the IBSHS model did not exhibit any notable radial cracking after $1 \mathrm{kN}$ and $1.5 \mathrm{kN}$ lateral load of cyclic loading. Nevertheless, the specimen showed noticeable radial cracking formed at the edge of the bottom columns during $4 \mathrm{kN}$ lateral load cycle. Conversely, at $6 \mathrm{kN}$ lateral load cycle the same radial crack lines extended towards the centre of the bottom columns where more cracks formed. Furthermore, the specimen manifested clear crack formation at the base of the columns. The $6.2 \mathrm{kN}$ lateral load failure cycle produced a few additional cracks with a notable increase in crack widths. Furthermore, the IBS beam did not reveal any evident radial cracking at mid-span until the end of the test.

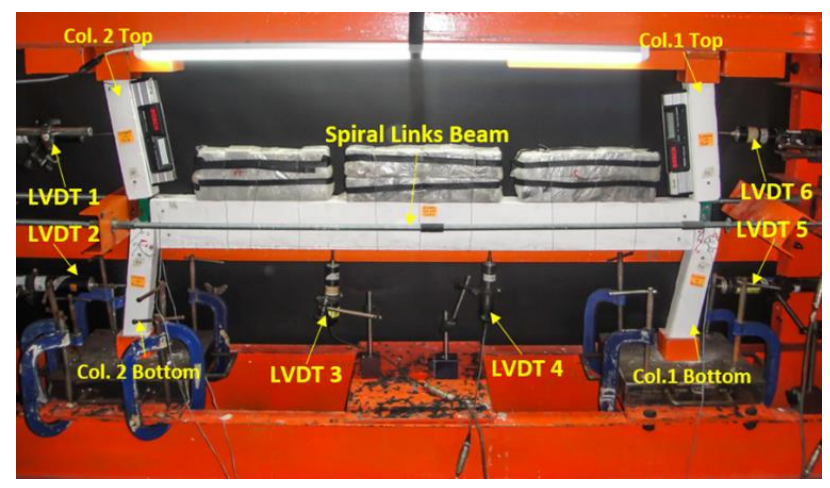

Figure 8 IBSHS model at the end of cyclic loading test (collapse)

Now, for the results on the $\mathrm{CRCH}$ system. Figures 9(a), (b), (c) and (b) illustrate the load-displacement curves of CRCH Column 2 Top (LVDT1), Column 1
Bottom (LVDT2), Column 1 Bottom (LVDT5), and Column 1 Top (LVDT6), respectively. The maximum horizontal displacement of fifth cyclic loading for LVDTI was determined to be $5.69 \mathrm{~mm}$ at $8.2 \mathrm{kN}$. The horizontal displacement and load at failure point were found to be $16.91 \mathrm{~mm}$ and $17 \mathrm{kN}$, respectively. The maximum horizontal displacement at fifth cyclic loading for LVDT2 was found to be $-0.05 \mathrm{~mm}$ at -8.9 $\mathrm{kN}$. The horizontal displacement and load at failure point was $0.12 \mathrm{~mm}$ for $17 \mathrm{kN}$. As shown in the diagram, the maximum horizontal displacement of the fifth cyclic loading for LVDT5 was $3.77 \mathrm{~mm}$ at 7.5 $\mathrm{kN}$. Moreover, the horizontal displacement and load at failure point were $11.11 \mathrm{~mm}$ and $17 \mathrm{kN}$, respectively. In addition, the maximum horizontal displacement of the fourth cyclic loading for LVDT6 was $5.34 \mathrm{~mm}$ at $7.5 \mathrm{kN}$. The horizontal displacement and load at failure point weredetermined to be 18.26 $\mathrm{mm}$ and $17 \mathrm{kN}$, respectively.
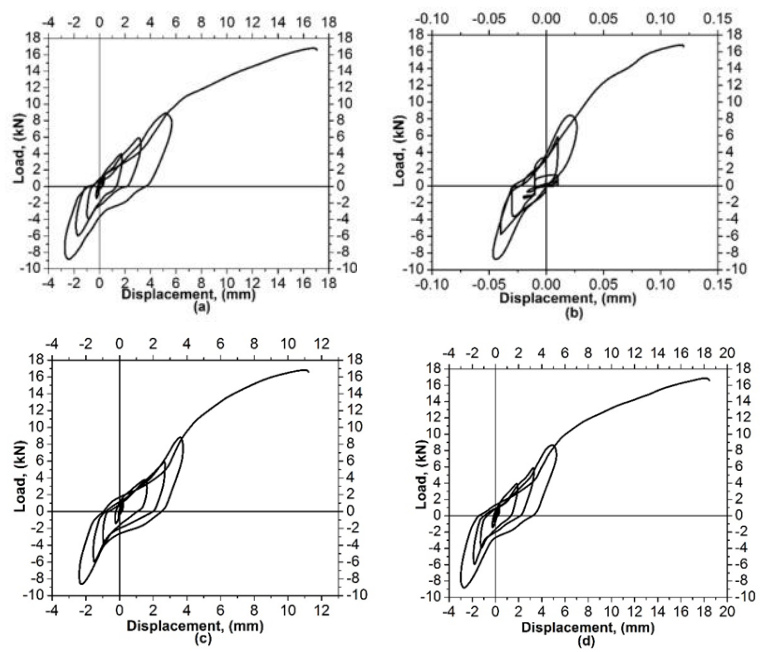

Figure 9 Load-displacement curves of $\mathrm{CRCH}$ (a) Column 2 Top (LVDT1), (b) Column 2 Bottom (LVDT2), (c) Column 1 Bottom (LVDT5) and (d) Column 1 Bottom (LVDT6)

Figure 10 shows the observed surface crack of CRCHS. The crack patterns of the top and bottom columns of the specimen occurring at the end of each cycle and at failure are also shown. The $\mathrm{CRCH}$ specimen did not show noticeable radial cracks after $1 \mathrm{kN}$ and $1.5 \mathrm{kN}$ lateral load cycles. Although, the specimen showed obvious radial crack development at the lower corners of beam-to-column connection after the $4 \mathrm{kN}$ lateral load cycle, at $6 \mathrm{kN}$ and $9 \mathrm{kN}$ lateral load cycles, the same radial crack lines extended towards the centre of the bottom columns where more cracks were formed at the upper end of the bottom columns, and at the lower end of the top columns. Meanwhile, the $17 \mathrm{kN}$ lateral load failure cycle produced a few additional cracks with a considerable increase in crack width. However, at the end of the test, the CRC beam did not exhibit any apparent radial cracks at the mid-span until the end of test. 


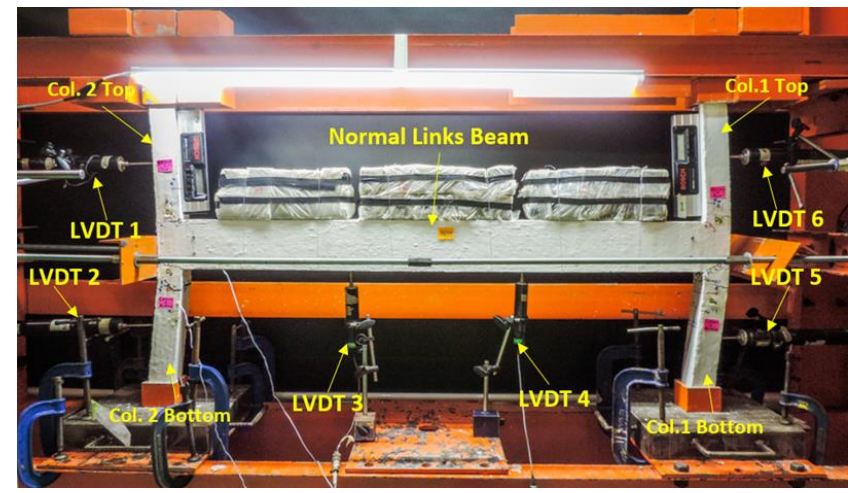

Figure $10 \mathrm{CRCH}$ model at the end of cyclic loading test (collapse)

The results for load-displacement and crack patterns obtained from IBSHN and IBSHS were compared with the $\mathrm{CRCH}$ model. Figure 11 shows a comparison of the load-displacement behaviour of IBSHN and IBSHS with CRCH at failure for Column 2 Top (LVDT 1). The slope of the load-displacement curve or the stiffness for $\mathrm{CRCH}$ was observed to be higher than IBSHN and IBSHS. This higher difference in stiffness values between the models is attributed to the weakness of IBS columns connection. The maximum load and displacement for IBSHN model were found to be $6.2 \mathrm{kN}$ and $23.06 \mathrm{~mm}$, respectively, and that of IBSHS model were $6.2 \mathrm{kN}$ and $15.56 \mathrm{~mm}$, respectively. Conversely, for $\mathrm{CRCH}$ the applied maximum load was $17 \mathrm{kN}$, and the observed displacement was $16.91 \mathrm{~mm}$. However, the observed displacement of $\mathrm{CRCH}$ at $6.1 \mathrm{kN}$ was $4.08 \mathrm{~mm}$. This signifies that under the same loading, IBSHN and IBSHS had a higher displacement than $\mathrm{CRCH}$.

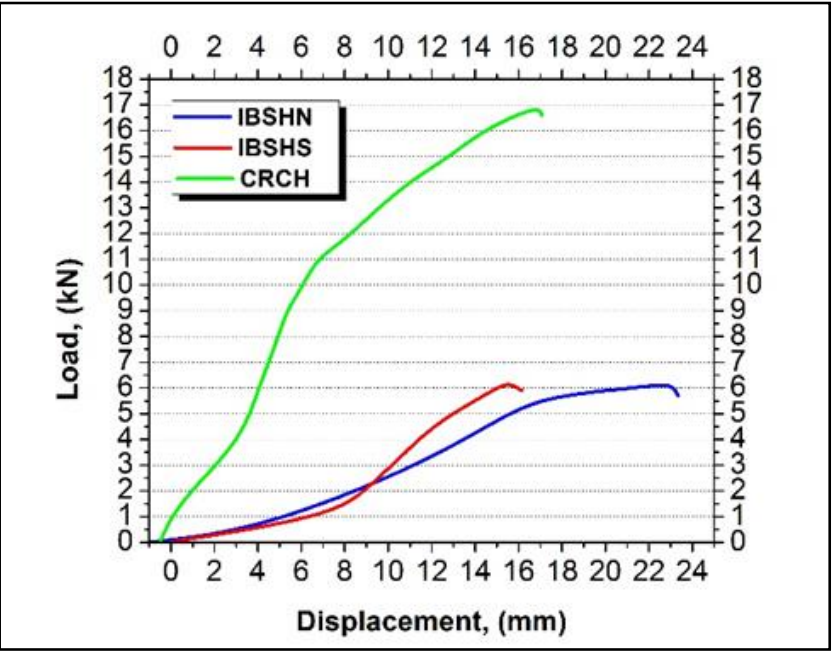

Figure 11 Comparison of IBSHN and IBSHS with $\mathrm{CRCH}$ model at failure for Column 2 Top (LVDT1)

Figure 12 shows the comparison of loaddisplacement behaviour of IBSHN and IBSHS with $\mathrm{CRCH}$ at failure for Column 1 Bottom (LVDT 5). Figure
12 also illustrates the comparison of loaddisplacement of IBSHN, IBSHS, and CRCH models at the final step of loading (failure loading) after the last cycle of the cycling loading. As shown in Figure 12, the slope of the load-displacement, or the stiffness of $\mathrm{CRCH}$ was more than IBSHN and IBSHS, and the difference between the stiffness of the models was big due to the weakness of IBS columns connection, where the maximum load and displacement that was applied for IBSHN model were $6.2 \mathrm{kN}$ and 25.13 $\mathrm{mm}$, respectively, and the maximum load and displacement that was applied for IBSHS model were $6.2 \mathrm{kN}$ and $15.52 \mathrm{~mm}$ respectively. On the other hand, the maximum load and displacement for $\mathrm{CRCH}$ were $17 \mathrm{kN}$ and $11.11 \mathrm{~mm}$, respectively. But the displacement of $\mathrm{CRCH}$ at $6.1 \mathrm{kN}$ was $3.07 \mathrm{~mm}$, which means that under the same loading IBSHN and IBSHS deflected more than $\mathrm{CRCH}$.

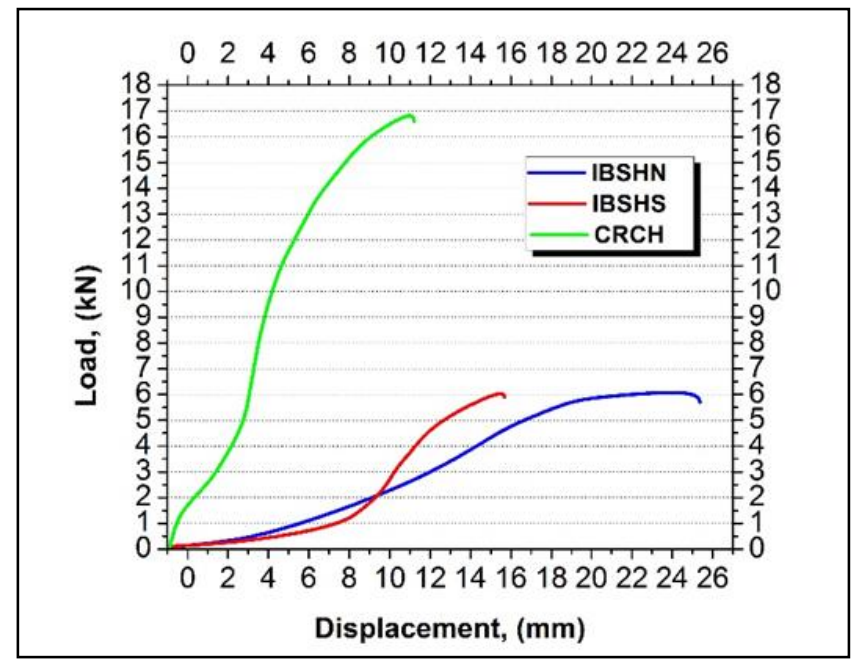

Figure 12 Comparison of IBSHN and IBSHS with $\mathrm{CRCH}$ model at failure for Column 1 Bottom (LVDT5)

Figures 13(a), (b) and (c) show a comparison of crack patterns at the end of the cyclic loading test for IBSHN, IBSHS and CRCH models, respectively. For all models, the cracks began to appear at the end of the third cycle of cyclic loading. In IBS models, the cracks began to appear in the area around the bottom columns of the steel box plate, while for CRC it started at the lower corners of beam-to-column connection. Furthermore, the IBS model under increasing load cycles exhibited the same radial crack lines extending outward from the centre of the bottom columns, and more cracks appearing at the upper end of the bottom columns, and at the lower end of the top columns. Conversely, there were less crack lines in the conventional model compared to the IBS models under the same cyclic loading. The CRC beam and IBS beams did not display any noticeable radial cracks until the end of the test. Nevertheless, the cracks occurred at the bases of columns during the failure cycle for IBSH models, 
while the CRC model did not reveal any cracks at the column bases.

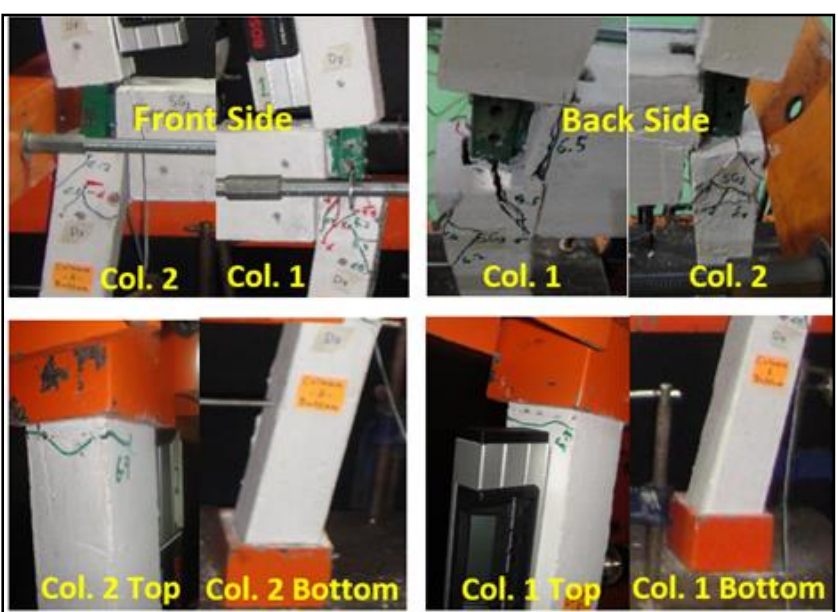

(b)

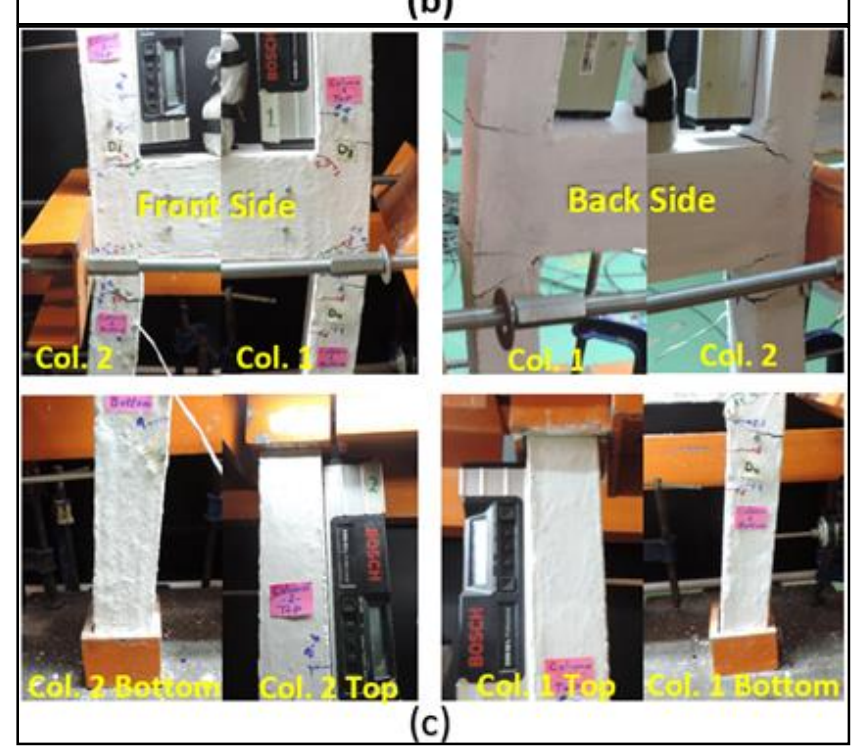

Figure 13 Crack patterns comparison at the end of cyclic loading test for models (a) IBSHN (b) IBSHS and (c) CRCH

\subsection{Load-Rotation}

The rotational performance of the IBS beam-tocolumn connection was investigated through loadrotation diagrams measured using inclinometer at zero and maximum load of each cycle of cyclic loading and failure loading. IBS connection rotation increased with the increase of loading for each push of cycle as shown in Figure 14. In Figure 14 (a), the maximum rotation for inclinometer No.1 was 0.141 rad at failure load $(6.2 \mathrm{kN})$, and in Figure 14 (b), the maximum rotation for inclinometer No.2 was 0.151 rad at failure load $(6.2 \mathrm{kN})$. The rotation of beam-tocolumn connection at each side was produced from the rotation of columns only because no crack occurred in the beam.
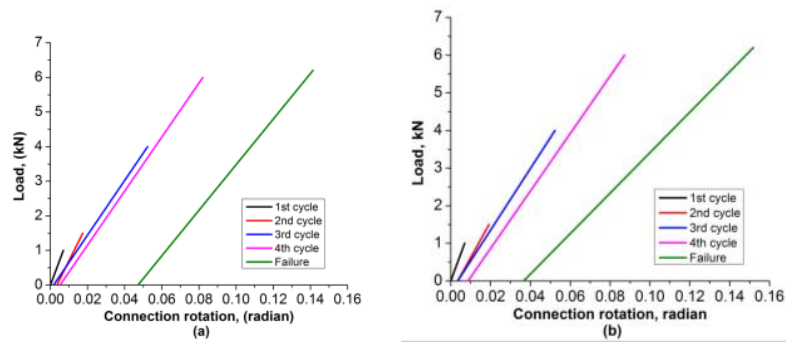

Figure 14 (a) Load-rotation of beam-to-column connection from inclinometer No.1 of IBSHN, (b) Load-rotation of beamto-column connection from inclinometer No.2 of IBSHN

The load-rotation of IBSHS inclinometer No.1 and inclinometer No.2 are shown in Figures 15(a) and (b), respectively. IBS connection rotation increased with the increase of loading for each push cycle. In Figure 15 (a), the maximum rotation for inclinometer No.1 was $0.136 \mathrm{rad}$ at failure load $(6.2 \mathrm{kN})$, and in Figure 15 (b), the maximum rotation for inclinometer No. 2 was $0.141 \mathrm{rad}$ at failure load $(6.2 \mathrm{kN})$. The beam did not display any cracks. Consequently, the rotation of the beam-to-column connection at each side was produced from the rotation of columns only.
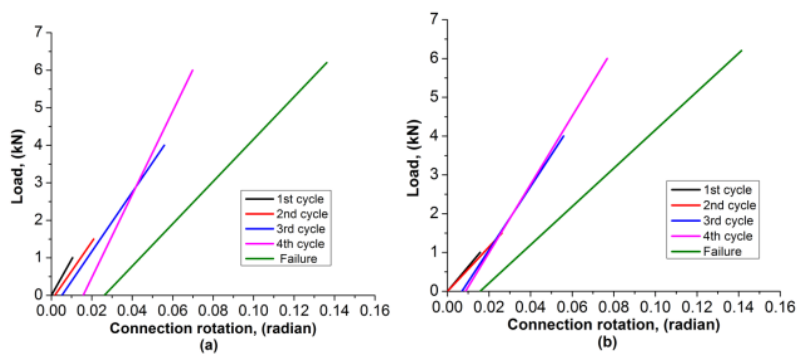

Figure 15 (a) Load-rotation of beam-to-column connection from inclinometer No.1 of IBSHS (b) Load-rotation of beamto-column connection from inclinometer No.2 of IBSHS

The results of the $\mathrm{CRCH}$ system are shown in Figure 16. In Figure 16 (a), the maximum rotation for inclinometer No.1 was $0.052 \mathrm{rad}$ at failure load (17 $\mathrm{kN})$. In Figure 16 (b), the maximum rotation for inclinometer No.2 was 0.054 rad at failure load (17 $\mathrm{kN})$. The rotation of beam-to-column connection at each side was produced from the rotation of columns only because no crack occurred in the beam.
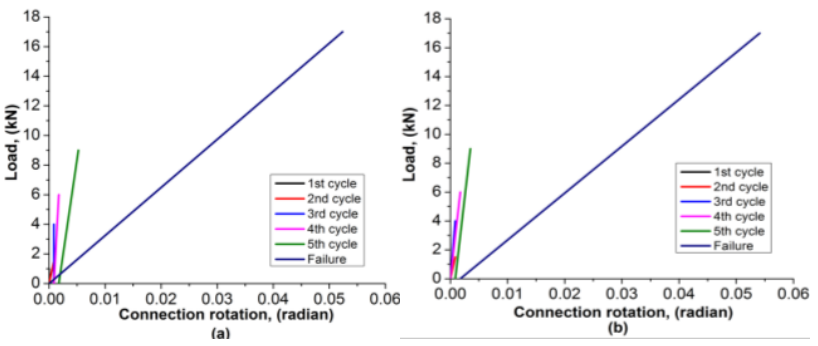

Figure 16 (a) Load-rotation of beam-to-column connection from inclinometer No.1 of CRCH, (b) Load-rotation of beamto-column connection from inclinometer No.2 of CRCH 


\subsection{CONCLUSION}

Experiments are performed on two IBS $\mathrm{H}$ models with different shear reinforcement for each beam, and hybrid beam-column connections via 1:5 cyclic loading. The results are compared with the performance of a reference monolithic beamcolumn connection. The parameters including load carrying capacity, displacement, and rotation are considered. Models such as IBSHN, IBSHS, and CRCH are studied, and their relationships in ductility are demonstrated. The conclusions which were illustrated in the following paragraphs were drawn on the basis of experimental observations.

The equal and comparable strength of IBS beams to that of $\mathrm{CRCH}$ model suggests that IBS can successfully be used for various applications.

The failure of all models occurs at the columns because it is not strong enough to support the lateral load, and not acceptable according to European Codes. Consequently, the column sections must be improved either by increasing the section dimensions or by reducing the thickness of the beam to create a strong column-weak beam condition.

The IBS connections of beams are sufficiently strong compared to the CRC connection under same cyclic loading. However, the connections of IBS models are weak at the interaction of box steel plate with reinforced concrete, and the failure load of $\mathrm{CRCH}$ is observed to be higher than IBS models. Accordingly, the interaction of steel box with concrete should be improved to get a better result.

Under same loading, the displacement of IBSHN and IBSHS is higher than that of CRCH. Thus, IBSHN and IBSHS offer more ductility than $\mathrm{CRCH}$ in terms of displacement capacity.

\section{Acknowledgement}

This research is partially supported by UTM-GUP Grants of Research for concrete of industrialize building system. The authors fully acknowledge support received from Universiti Teknologi Malaysia, Skudai.

\section{References}

[1] Moghadasi, M., \& Marsono, A. K. 2012. Comparative Experimental Study of Full-scale H-Subframe Using a New Industrialized Building System and Monolithic Reinforced Concrete Beam-to-Column Connection. The Structural Design of Tall and Special Buildings.
[2] Kamar, K. A. M., Hamid, Z. A., Azman, M. N. A., Ahamad, M. S. S. 2011. Industrialized Building System (IBS): Revisiting Issue of Definition and Classification. International Journal of Emerging Sciences. 1 (2): 120-132.

[3] Moghadasi, M., Marsono, A. K., \& Mohammadyan-Yasouj, S. E. 2017. A Study on Rotational Behaviour of a New Industrialised Building System Connection. Steel and Composite Structures. 25(2): 245-255.

[4] Richard, R. B. 2005. Reproduction before Automation and Robotics. Journal of Automation in Construction. 14: 251441.

[5] Mydin, M. O., Sani, N. M., \& Taib, M. 2014. Industrialised Building System in Malaysia: A Review. MATEC Web of Conferences. EDP Sciences. 10: 01002.

[6] Fateh, M. A. M., \& Mohammad, M. F. 2017. Industrialized Building System (IBS) Provision in Local and International Standard Form of Contracts. Journal of Construction in Developing Countries. 22(2): 67-80.

[7] Warszawski, A. 2004. Industrialized and Automated Building Systems: A Managerial Approach. Taylor \& Francis.

[8] Olteanu, I., Ciongradi, I. P., Anechitei, M. and Budescu, M. (2009). The Ductile Design Concept for Seismic Actions in Miscellaneous Design Codes. Bulletin of the Polytechnic Institute of Jassy, Constructions, Architechture Section, 55.

[9] Ghayeb, H. H., Razak, H. A., \& Sulong, N. R. 2017. Development and Testing of Hybrid Precast Concrete Beam-to-Column Connections under Cyclic Loading. Construction and Building Materials. 151: 258-278.

[10] Engström B. 2008. Structural Connections for Precast Concrete Buildings. (43). Lausanne, Switzerland: the International Federation for Structural Concrete (fib).

[11] Castro, J. J., Yamaguchi, T. and Imai, H. 1994. Seismic Performance of Precast Concrete Beam-Column Joints. Journal of Structural Construction Engineering. 455: 113-26.

[12] Li, B., Kulkarani, S.A. and Leong, C. L. 2009. Seismic Performance of Precast Hybrid-Steel Concrete Connections. Journal of Earthquake Engineering. 1(35): 667-689.

[13] Xue, W. and Yang, X. 2010. Seismic Tests of Precast Concrete Moment Resisting Frames and Connections. PCl Journal. 55(3): 102-121.

[14] Vidjeapriya, R., Vasanthalakshmi, V. and Jaya, K. P. 2013. Performance of Exterior Precast Dowel Connections under Cyclic Loading Beam-Column Dowel Connections under Cyclic Loading. International Journal of Civil Engineering. 12(1): 82-95.

[15] Ghayeb, H. H., Razak, H. A., \& Sulong, N. R. 2017. Development and Testing of Hybrid Precast Concrete Beam-to-Column Connections under Cyclic Loading. Construction and Building Materials. 151: 258-278.

[16] British Standards Institution. 2004. Eurocode 2: Design of Concrete Structures: Part 1-1: General Rules and Rules for Buildings. British Standards Institution.

[17] Standard, B. 2005. Eurocode 8: Design of Structures for Earthquake Resistance.

[18] FEMA-273. 1997. NEHRP Guidelines for the Seismic Rehabilitation Of Buildings, Report No. FEMA-273, Federal Emergency Management Agency, Washington, D.C.

[19] FEMA-356. 2000. Prestandard and Commentary for the Seismic Rehabilitation of Buildings, Report No. FEMA-356, Federal Emergency Management Agency, Washington, D.C. 